\title{
PERAN MEDIA GAMBAR DALAM MENINGKATKAN PEMAHAMAN SISWA TENTANG KONSEP HAK ANAK
}

\author{
Maimunah \\ SDN 5 Rantau Panjang Kalimantan Barat \\ Email: maimun234@gmail.com
}

\begin{abstract}
Abstraks
PKn subject learning about children's rights at home and at school, an evaluation was held, the results of which were obtained data of 5 students from 27 first semester students of SDN 5 Rantau Panjang Simpang Hilir Subdistrict, North Kayong District, below 65 or 19.34\% yet reach the specified KBM of 65, and even the class average value is still low at 80.66. The purpose of our learning improvement research is to improve students' understanding of their rights at home and school using picture media. By using image media during the two research cycles Observations on the results of the formative test cycle II showed good and satisfying results, with a total of 22 students already getting 70 and above.
\end{abstract}

Kata Kunci : Penggunaan, Media Gambar

\section{PENDAHULUAN}

Masalah Guru dalam konteknya sebagai pengajar disekolah, mempunyai tanggung jawab yang tidak ringan. Sebagai ujung tombak melesatkan siswa agar mencapai tujuan pembelajaran yang diharapkan, ia harus mampu mengelola proses pembelajaran dengan baik, memahami karakteristik siswa, menguasai materi untuk diterjemahkan di dalam kelasnya. Tetapi siswa sebagai peserta didik yang mempunyai intelegensi, motivasi, gaya belajar dan temperamen yang berbeda-beda, menjadikan ada siswa yang cerdas, ada yang lambat dan ada yang sulit dalam penguasaan materi pembelajaran yang diberikan oleh guru.

Menurut Gagne, belajar PKn merupakan keinginan untukmempelajari PKn mulai dari proses, terbentuknya suatu proses kemudian berlatih menuangkan dan memanipulasi konsep-konsep tersebut pada situasi baru yang mengutamakan pengertian bukannya hafalan (Erman S, 1995) Pada akhir pembelajaran mata pelajaran PKn tentang hak anak di rumah dan di sekolah, diadakan evaluasi, hasilnya diperoleh data 5 siswa dari 27 siswa kelas 1 semester II SDN 5 Rantau Panjang Kecamatan Simpang Hilir, Kabupaten Kayong Utara nilainya dibawah 65 atau 19,34 \% belum mencapai KBM yang ditetapkan yaitu 65 , serta nilai rata-rata kelaspun masih rendah yakni 80,66. menurut
Lukman, belajar adalah berusaha memperoleh kepandaian atau ilmu atau perubahan tingkah laku atau tanggapan yang disebabkan oleh pengalaman (Lukman).

Untuk siswa yang lambat dan sulit menguasai materi pembelajaran, guru sebagai pengelola pengelola pembelajaran bertanggung jawab mengupayakan agar siswa menguasai tujuan pembelajaran yang sudah ditetapkan. Pembelajaran melalui PTK (Penelitian Tindakan Kelas). Witherington merumuskan bahwa belajar sebagau suatu perubahan dalam kepribadian. Sebagaimana yang dimanifestasikan dalam perubahan penguasaan pola-pola respons atau tingkah laku yang baru yang ternyata dalam perubahan ketrampilan kebiasaan kesanggupan atau pemahaman (Witherington, 1965).

Evaluasi yang penulis lakukan pada kegiatan akhir, untuk mengetahui tingkat penguasaan siswa terhadap materi pembelajaran diperoleh data $19,34 \%$ tidak menguasai materi pembelajaran. Rendahnya prestasi ini membuat penulis tidak puas, untuk itu penulis mengadakan refleksi diri dengan menyusun sejumlah pertanyaan refleksi. Masalah prestasi ini penulis angkat sebagai PTK sebab bila tidak diatasi akan berdampak buruk bagi sekolah yakni menurunnya kualitas pembelajaran

Berdasarkan jawaban refleksi dan diskusi teman sejawat, masalah rendahnya prestasi 
dapat penulis identifikasikan sebagai berikut a) Sebagian besar siswa tidak memperhatikan penjelasan guru. b) Sebagian besar siswa tidak dapat menjawab pertanyaan guru.

Berdasarkan identifikasi masalah siswa tidak memperhatikan penjelasan guru tentang "Hak anak di rumah dan di sekolah", penulis mencoba menganalisa faktor-faktor penyebabnya a) Terbatasnya kosa kata yang dimiliki siswa. b) Siswa tidak diberi kesempatan untuk bertanya. c) Siswa tidak diberi teks materi. d) Penjelasan guru didominasi dengan metode ceramah. e) Dalam penjelasan guru tidak menggunakan alat peraga. f) Guru tidak memberi kesempatan siswa bertanya. g) Bahasa yang digunakan guru tidak dipahami siswa.

Jean Peaget menggolongkan usia 6/7 tahun untuk kelas I, berfikirnya dalam tahap operasional konkrit dan serba nyata. Jadi penggunaan metode ceramah tanpa disertai alat peraga, akan membosankan dan tidak tertanam dalam struktur kognitif siswa, juga dalam buku Tes dan Asemen di SD menyebutkan usia 6/7 tahun perbendaharaan kata siswa + baru mencapai 2500 kata, mungkin kata yang diucapkan guru ada yang tidak masuk dalam daftar 2500 kata tersebut.

Berdasarkan identifikasi masalah, penjelasan guru dalam menyampaikan materi hak anak di rumah dan di sekolah kurang dipahami siswa, penulis merumuskan masalah "Bagaimana Cara Meningkatkan Pemahaman Siswa Tentang Konsep Hak Anak di Rumah dan di Sekolah dengan Media Gambar di Kelas I SDN 5 Rantau Panjang ?”.

Tujuan penelitian perbaikan pembelajaran yang kami lakukan adalah untuk meningkatkan pemahaman siswa tentang haknya dirumah dan disekolah.

Dalam penelitian ini, keberhasilan penelitian apa bila hasil tes siswa sudah berada dalam tingkat yang ditetapkan. Dalam penelitian ini ketercapaian dapat dilihat dari interval dalam katagori baik ( interval nilai 60 - 79).

Pengertian strategi pembelajaran adalah pendekatan, prosedur, metode, model dan teknik yang dipergunakan dalam menyajikan bahan/ isi kurikulum. Sudjana (1988) mengemukakan bahwa strategi pembelajaran pada hakekatnya adalah tindakan nyata dari guru dalam melaksanakan pembelajaran melalui cara tertentu yang dinilai lebih efektik dan lebih efisien. Dengan kata lain, strategi berhubungan dengan siasat atau taktik yang digunakan guru dalam melaksanakan kurikulum secara sistemik dan sistimatik, sistemik mengandung arti adanya saling keterkaitan antara komponen kurikulum sehingga terorganisasikan secara terpadu dalam mencapai tujuan, sedangkan sistemik mengandung arti bahwa langkah-langkah yang dilakukan guru secara berurutan sehingga mendukung tercapainya tujuan.

Menurut Lukman, belajar adalah berusaha memperoleh kepandaian atau ilmu atau perubahan lingkah laku atau tanggapan yang disebabkan oleh pengalaman (Lukman). Menurut peneliti, belajar adalah suatu proses yang komplek yang terjadi pada semua orang yang ditandai dengan adanya perubahanperubahan akibat proses belajar, seperti perubahan pengetahuan, pemahaman konsep, ketrampilan, tingkah laku, kecakapan dan kemampuan pada diri seseorang. Secara umum tugas guru dalam kegiatan pembelajaran adalah sebagai fasilitator yang bertugas menciptakan situasi yang memungkinkan terjadinya proses belajar pada diri siswa.

Dalam menjalankan tugasnya sebagai fasilitator, ada dua tugas yang harus dilaksanakan guru dalam kegiatan pembelajaran yang efektif. Kedua tugas tersebut sebagai pengelola pembelajaran dan sebagai pengelola kelas. Sebagai pengelola pembelajaran guru bertugas untuk menciptakan kegiatan pembelajaran yang memungkinkan siswa mencapai tujuan pembelajaran secara optimal. Dalam melaksamnakan tugasnya sebagai pengajar guru harus memainkan berbagai peranan, diantaranya sebagai manusia sumber komunikator, mediator, pembimbing dan peneliti.

Berkaitan dengan perannya sebagai manusia sumber, guru harus mampu menyampaikan informasi tersebut dapat dipahami oleh siswa (sebagai komunikator) gaya penyajian yang digunakan guru dalam membahas materi pembelajaran berpengaruh terhadap perhatian siswa. Menurut pendapat Slavin (Suciati, dkk 2005 : 5,19), materi pelajaran hendaknya 
disajikan dengan cara yang menarik sehingga rasa ingin tahu siswa siswa terhadap materi pelajaran meningkat. Oleh karena itu, guru dituntut untuk menggunakan metode dan media yang bervariasi agar siswa terlibat aktif dalam pembelajaran.

Penyampaian materi hak anak di rumah dan di sekolah di kelas I bila hanya menggunakan metode ceramah apa yang menjadi tujuan pembelajaran tidak tercapai dengan optimal sebab ditinjau dari pengertian, kata hak adalah sesuatu yang abstrak. Untuik siswa kelas I yang berusia 6/7 tahun, menurut Jean Peaget taraf berfikirnya kategori preoperasional periode dalam tahapan intuitif. Dimana siswa hanya dapat memahami melalui pengamatan yang bersifat egosentrik (berpusat pada dirinya, belum memahami cara orang lain memandang untuk objek yang sama). Juga dalam buku Tes dan Asesmen, hasil penelitian perbendaharaan kata anak usia 6/7 tahun baru mencapai +2500 kata. Bisa jadi kata hak tidak termasuk dalam perbendaharaan kata yang dimiliki oleh siswa. Jadi kata hak adalah suatu kata yang asing bagi siswa.

Agar materi anak di rumah dan di sekolah dapat dipahami oleh siswa kelas I dengan baik, guru perlu suatu strategi dalam penyampaiannya. Melihat karakteristik siswa kelas I bahwa hal - hal yang bersifat konkret lebih mudah dipahami dari pada yang abstrak, kemampuan mengingat (memori) dan berbahasa berkembang sangat cepat, sebaiknya dalam menyampaikan materi guru menggunakan alat peraga berupa gambar yang dialami siswa di rumah dan di sekolah serta mengajak siswa bercakap dengan bertanya jawab tentang gambar yang diperlihatkan guru, dan menjelaskan kata-kata yang tidak dipahami oleh siswa.

Materi hak anak di rumah dan di sekolah sebenarnya sejalan atau relevan dengan kebutuhan siswa. Bila siswa benar-benar memahaminya, belajar akan mempunyai makna pada diri siswa, siswa sadar akan haknya. Sependapat dengan prinsip belajar menurut Carl Rogers (65: 1969) belajar bermakna bila materi relevan dengan kebutuhan anak. Oleh sebab itu agar siswa dalam belajar memperoleh makna, guru dalam perbaikan pembelajarannya :
1. Menggunakan metode yang bervariasi.

2. Menggunakan alat peraga yang sesuai dengan materi.

3. Menambah dan memperluas perbendaharaan kata siswa.

4. Menggunakan bahasa yang mudah dipahami siswa.

Metode dan strategi pengajaran yang dapat mengatasi dan mencapai tujuan pelajaran PKn pada pokok bahasan hak anak dirumah dan di sekolah adalah menggunakan metode ceramah bervariasi. Metode ceramah bervariasi mempunyai keuntungan sebagai berikut : (1) Dapat digunakan untuk menyajikan beberapa materi dalam satu kali sajian sehingga waktu menjadi lebif efisien. Dengan cara ini diharapkan materi pelajaran dapat diselesaikan sesuai dengan waktu yang disediakan dengan penyajian yang bermakna dan menarik. (2) Dapat mengaktifkan siswa dalam pembelajaran. (3) Menunjukkan daya tarik siswa dalam belajar karena ssiswa dapat terlibat langsung dalam pembahasan dan materinya. (4) Meningkatkan rasa percaya diri. (5) Mengaktifkan penggunaan pendekatan ketrampilan proses dalam melaksanakan pembelajaran sehingga dapat meningkatkan kecerdasan siswa.

Proses belajar mengajar dengan menggunakan metode ceramah bervariasi akan memudahkan guru ataupun siswa dalam menginternalisasi konsep-konsep dan nilai-nilai dari suatu pengetahuan. Dengan metode ceramah bervariasi, kegiatan dan keterlibatan siswa sangat tinggi dalam pelajaran serta mampu meningkatkan motivasi siswa dalam pembelajaran PKn.

Pengertian motivasi menurut Gleitmen (1986) dan Reber (1988), yang dikutip Syah (2006), motivasi adalah keadaan internal baik manusia maupun hewan yang memdorong untuk berbuat sesuatu. Motivasi dapat dibedakan menjadi menurut sumbernya, yaitu motivasi intrinsik dan motivasi ekstrinsik. Motivasi intrinsik adalah dorongan untuk berbuat sesuatu yang berasal dari dalam diri seseorang atau siswa untuk belajar.

Contoh motivasi intrinsik adalah menyenangi pelajaran tertentu dan motivasi berprestasi. Sedangkan motivasi ekstrinsik adalah dorongan untuk berbuat sesuatu atau 
belajar sesuatu secara tekun yang berasal dari luar individu seseorang atau siswa.

Contoh motivasi ekstrinsik adalah pujian, hukuman (teguran, sanksi), peraturan, suri tuladan. Dalam kaitannya dengan motivasi belajar, motivasi yang penting atau signifikan terhadap hasil belajar adalah motivasi intrinsik karena lebih murni dan langgeng serta tidak tergantung dari orang luar. Hasil belajar merupakan hal penting dalam proses belajar mengajar, karena dapat menjadi petunjuk untuk mengetahui sejauh mana keberhasilan siswa dalam kegiatan belajar mengajar yang telah dilaksanakan. Dengan demikian, jika pencapaian hasil belajar itu tinggi dapat dikatakan bahwa proses belajar mengajar itu berhasil.

Hasil belajar adalah hasil yang dicapai oleh seorang siswa setelah melakukan suatu usaha untuk memenuhi kebutuhannya. Usaha tersebut dipengaruhi oleh kondisi dan situasi tertentu, yaitu pendidikan dan latihan dalam suatu jenjang tertentu. Menurut Sudjana (1991), penilaian hasil belajar adalah proses pemberian nilai terhadap hasil-hasil belajar yang dicapai siswa dengan kriteria tertentu. Menurut Arikunto (2001), hasil belajar sebagai indikator perubahan terhadap tingkah laku yang meliputi 3 ranah, yaitu kognitif (pemahaman), afektif (sikap), dan psikomotorik (ketrampilan). Dengan cara memotivasi siswa maka dalam pembelajaran PKn tentang hak anak di rumah dan di sekolah berhasil dengan baik.

Gambar merupakan alat atau bahan yang mengandung informasi dan fakta. Fungsi gambar dalam pembelajaran menurut Hornby (dalam Nursiyani, 2002:46) adalah : (1) Memperjelas keterangan guru. (2) Memperkuat pemahaman siswa pada suatu konteks atau tema pembelajaran. (3) Membangkitkan minat atau motivasi siswa. (4) Menumbuhkan daya cipta siswa dengan merangkaikan kata-kata menjadi kalimat. (5) Menjadikan proses pembelajaran berlangsung secara kondusif. (5) Mencegah rasa bosan.

Menurut Schram (1977) mengemukakan bahwa meedia pembelajaran adalah teknologi pembawa pesan yang dapat dimanfaatkan untuk keperluan pembelajaran. Dengan media gambar siswa lebih cepat memahami materi pembelajaran sehingga dapat meningkatkan prestasi belajar siswa. Sementara itu, Briggs (1977) berpendapat bahwa media pembelajaran adalah sarana fisik untuk menyampaikan isi / materi pembelajaran seperti : buku, film, video dan sebagainya.

Dengan menggunakan media pembelajaran secara fisik seperti buku, film video dan sebagainya anak dapat secara langsung membaca dan melihat sehingga dapat meningkatkan prestasi belajar siswa.

\section{METODE}

Perbaikan pembelajaran dilaksanakan di kelas I SD Negeri 5 Rantau Panjang, Kecamatan Simpang Hilir, Kabupaten Kayong Utara, Kalimantan Barat, yang dimulai dari tanggal 1 Februari 2018 sampai 2 Mei 2018. Adapun jadwal pelaksanaan pembelajaran untuk mata pelajaran PKn adalah sebagai berikut : (a) Tanggal 2 Maret 2018 mata pelajaran PKn Siklus I. (b) Tanggal 6 April mata pelajaran PKn Siklus II.

Subjek penelitian kelas I, dengan jumlah 27 siswa yang terdiri dari 17 siswa laki-laki dan 10 siswa perempuan. Dari 27 siswa tersebut, 20\% siswa berkemampuan tinggi, 55\% siswa berkemampuan sedang, dan $25 \%$ siswa berkemampuan rendah.

\section{Siklus I}

Pada siklus I guru merencanakan pembelajaran dengan metode tanya jawab, ceramah, demonstrasi, latihan, dan penugasan. Guru menjelaskan materi pembelajaran dengan menggunakan alat peraga tentang hak anak di sekolah dan di rumah. Guru mengkondisikan siswa dan menyampaikan tujuan pembelajaran yang akan dicapai.

Langkah-langkah yang ditempuh dalam pelaksanaan pembelajaran PKn pada siklus I adalah : (1) Guru memberikan bacaan hak anak di rumah dan di sekolah. (2) Guru memberikan kesempatan kepada siswa untuk menanyakan kata-kata yang tidak dipahami. (3) Guru menjelaskan kata-kata yang tidak dipahami siswa. (4) Guru Menjelaskan kembali materi hak anak di rumah dan di sekolah.

Sebagai pengamat dam kegiatan pembelajaran ini peneliti dibantu oleh teman 
sejawat dengan menggunakan lembar observasi. Dari hasil pengamatan selama perbaikan pembelajaran berlangsung muncul hal-hal sebagai berikut : (1) Beberapa siswa kurang memperhatikan pelajaran. (2) Sebagian siswa sudah aktif dalam pembelajaran. (3) Siswa yang merasa belum jelas sudah berani bertanya. (4) Semua siswa menyelesaikan tugas dengan baik.

Dengan penjelasan guru tentang hak anak dirumah dan di sekolah, siswa lebih memahami materi pembelajaran. Untuk mengetahui berapa jauh ketrampilan dan pemahaman siswa tentang hak anak di rumah dan di sekolah guru memberi evaluasi yang dikerjakan secara individu. Dari data yang diperoleh, nilai formatif siklus I mengalami peningkatan dari sebelum perbaikan pembelajaran.

a. Refleksi

Setelah selesai pembelajaran siklus I, peneliti melakukan refleksi dengan dibantu teman sejawat. Dalam pelaksanaan pembelajaran tersebut, sebagian besar siswa sudah aktif dalam pembelajaran, karena guru sudah menggunakan alat peraga tentang hak anak di rumah dan di sekolah dalam metode penerapan. Namun karena masih terdapat siswa yang kurang memperhatikan pelajaran, maka guru akan memperbaiki proses pembelajaran pada siklus II dengan memberi tugas tentang hak anak di rumah dan di sekolah, untuk lebih meningkatkan pemahaman siswa maka guru lebih banyak memberikan motivasi kepada siswa tentang hak anak di rumah dan di sekolah, sehingga prestasi siswa meningkat.

\section{Siklus II}

\section{a. Perencanaan Tindakan}

Pada siklus II ini, penggunaan alat peraga dan metode tanya jawab untuk meningkatkan pemahaman siswa terhadap materi hak anak di rumah dan di sekolah. Perencanaan pembelajaran masih menggunakan metode ceramah bervariasi, demonstrasi dan penugasan. Untuk lebih menarik siswa, demontrasi alat peraga tentang hak anak di rumah dan di sekolah dan guru menjelaskannya. Guru akan lebih meningkatkan motivasi siswa dengan memberikan pujian tentang sikap siswa di rumah dan di sekolah.

\section{b. Pelaksanaan Tindakan}

Setelah guru menyampaikan tujuan pembelajaran, guru melaksanakan langkahlangkah yang ditempuh dalam perbaikan pembelajaran PKn sebagai berikut : (1) Guru mengajukan apersepsi dengan mengajukan pertanyaan. (2) Guru memperlihatkan gambar yang sesuai dengan materi. (3) Guru dan siswa mengadakan tanya jawab tentang gambar yang diperlihatkan guru. (4) Guru menjelaskan hak anak di rumah dan di sekolah. (5) Guru memberi kesempatan siswa untuk bertanya. (6) Siswa mengerjakan evaluasi. (7) Menilai hasil tes dan menganalisa. (8) Memberi PR untuk latihan.

\section{c. Pengamatan ( Observasi)}

Peneliti melakukan pengamatan dengan dibantu teman sejawat dari hasil siklus II, selama perbaikan pembelajaran berlangsung terjadi peningkatan sebagai berikut : (1) Perhatian siswa tertahap materi pembelajaran meningkat. (2) Siswa sudah berani mengemukakan pendapat atau bertanya. (3) Siswa aktif dalam pembelajaran. (4) Semua siswa menyelesaikan tugas dengan baik. (5)Terjadi peningkatan motivasi pada diri siswa dengan adanya gambar hak anak di rumah dan di sekolah.

Penerapan metode tanya jawab dengan bimbingan guru sangat membentu pemahaman siswa. Motivasi siswa lebih meningkat dengan umpan balik yang diberikan guru berbentuk alat peraga tentang hak anak di rumah dan di sekolah. Dari data yang diperoleh hasil tes formatif perbaikan pembelajaran silkus II mengalami peningkatan dari siklus I. hal ini membuktikan bahwa metode yang dipilih yaitu metode tanya jawab dengan alat peraga dan pemberian motivasi guru dapat meningkatkan prestasi belajar siswa.

\section{d. Refleksi}

Berdasarkan hasil observasi dan masukan teman sejawat, peneliti melakukan refleksi. Penerapan metode tanya jawab dengan melibatkan siswa pada mata pelajaran PKn tentang hak anak di rumah dan di sekolah lebih menarik perhatian siswa. Dan metode tanya jawab sangat tepat untuk meningkatkan ketrampilan dan pemahaman siswa dalam hak 
anak di rumah dan di sekolah. Selain itu, hasil siswa dengan dibahas serta diberi pujian atau komentar juga akan meningkatkan moptivasi siswa. Pemahaman siswa lebih meningkat, dengan merancang dan melakukan tindakan perbaikan guru memiliki ketrampilan yang meningkat dalam mengelola KBM. Jumlah siswa 27 sudah tuntas mencapai KKM. 65 keatas semuanya, siswa masih tetap diberi motivasi agar meningkatkan belajarnya.

Cara pengumpulan data dengan menggunakan model observasi dan model tes. Data diperoleh dengan observasi yang dilengkapi dengan lembar pengamatan dan diskriptif.

Data penelitian yang peneliti kumpulkan adalah : (1) Tabel pengamatan partisipasi dalam mengikuti proses pembelajaran di dalam kelas. (2) Tabel analisis perolehan nilai hasil ulangan harian. (3) Instrumen penelitian yang digunakan oleh peneliti sebagai berikut: (1) Rencana Pembelajaran (RP), rencana pembelajaran yang penulis susun sesuai dengan pendekatan dan metode pembelajaran. (2) Lembar observasi siswa, Lembar observasi siswa disusun untuk mengetahui rata-rata tingkat aktivitas siswa, dan dilaksanakan tiap-tiap pertemuan.

1. Lembar observasi guru

Lembar observasi guru disusun untuk mengetahui rata-rata tingkat aktivitas guru dalam proses pembelajaran, dan dilaksanakan tiap-tiap siklus.

2. Lembar kerja siswa (LKS)

Lembar kerja siswa disusun dan diberikan kepada siswa untuk melatih ketrampilan dalam menyelesaikan bentuk-bentuk soal-soal cerita, selain itu digunakan untuk mengetahui tingkat pemahaman siswa dalam menyelesaikan soal.

\section{Tes akhir}

Tes akhir dilaksanakan pada tiap-tiap akhir siklus, yaitu pada pertemuan keempat untuk siklus satu dan pertemuan kedelapan untuk siklus kedua. Hasil dari tes akhir ini digunakan untuk mengukur tingkat ketuntasan belajar.

\section{HASIL DAN PEMBAHASAN Hasil}

Siklus I menunjukkan bahwa prestasi siswa belum optimal karena minat dan perhatian belum menyeluruh. Untuk lebih meningkatkan ketrampilan dan pemahaman siswa tentang materi hak anak di rumah dan di sekolah guru menggunakan alat peraga berupa gambar hak anak di rumah dan di sekolah. Hal tersebut dapat meningkatkan prestasi belajar siswa. Namun peningkatan prestasi belum optimal karena motivasi siswa masih kurang.

Pada perbaikan pembelajaran siklus II minat dan perhatian siswa sudah menyeluruh, suasana kelas lebih siap, siswa sudah berani bertanya dan semua siswa melaksanakan tugas dengan baik. Perbaikan pembelajaran yang dilaksanakan dapat meningkatkan prestasi belajar siswa karena guru selalu mempersiapkan kondisi awal siswa sebelum pembelajaran, menggunakan alat peraga / contoh gambar hak anak di rumah dan di sekolah, mengoptimalkann metode tanya jawab dan ceramah bervariasi, serta memberikan umpan balik terhadap siswa.

Peningkatan minat dan prestasi belajar siswa tersebut dapat tercapai karena :

1. Guru selalu mempersiapkan kondisi awal siswa sebelum kegiatan pembelajaran. Sebab, mempersiapkan kondisi awal siswa sebelum kegiatan pembelajaran merupakan salah satu faktor keberhasilan dalam pembelajaran. Dengan langkah tersebut, siswa akan merasa siap dan tenang dalam menerima pelajaran karena terfokus pada kegiatan pembelajaran. Menurut pendapat Slavin (Suciati dkk, 2005 ; 5,19 ), materi pelajaran hendaknya disajikan dengan cara yang menarik sehingga rasa ingin tahu siswa terhadap materi pelajaran meningkat. Oleh karena itu, guru dituntut untuk menggunakan metode dan media yang bervariasi agar siswa terlibat aktif dalam pembelajaran.

2. Guru menggunakan alat peraga yang tepat dalam pembelajaran hak anak di rumah dan di sekolah. Penggunaan alat peraga gambar tersebut dengan didemonstrasikan untuk diamati oleh setiap siswa. Dengan alat tersebut siswa mempunyai gambaran yang lebih konkret tentang hak anak di rumah dan di sekolah. Untuk siswa kelas I yang berusia 6/7 tahun, menurut Jean Peaget taraf berfikirnya kategori preo[erasional periode dalam tahapan intuitif. Dimana siswa hanya dapat memahami melalui pengamatan yang bersifat egosentrik (berpusat 
pada dirinya, belum memahami cara orang lain memandang untuk objek yang sama).

3. Guru menggunakan metode tanya jawab dan ceramah bervariasi, sebagai metode yang dirasa tepat untuk meningkatkan ketrampilan siswa dalam materi hak anak di rumah dan di sekolah. Maka kecerdasan anak akan semakin meningkat karena pengetahuan anak membutuhkan proses. Bila siswa benar-benar memahaminya, belajar akan mempunyai makna pada diri siswa, siswa sadar akan haknya. Sependapat dengan prinsip belajar menurut Carl Rogers (65 : 1969 ) belajar bermakna bila materi relevan dengan kebutuhan anak

4. Guru meningkatkan motivasi siswa dengan memberikan umpan balik (feed back) dalam bentuk hasil belajar siswa yang baik dengan disertai komentar maupun pujian. Menurut Gleitmen (1986) dan Reber (1988), yang dikutip Syah (2006), motivasi adalah keadaan internal baik manusia maupun hewan yang mendorong untuk berbuat sesuatu.

Menurut pendapat Wright (Suciati, dkk, $2005: 5-20$ ), tugas guru sebagai pengelola pembelajaran dan pengelola kelas yang harus dilakukan guru untuk memotivasi belajar siswa adalah : Tunjukkan sikap positif, beri kegiatan bermakna, tunjukkan semangat belajar, terapkan disiplin fleksibel, beri kesempatan siswa aktif, beri kesempatan siswa menilai diri, dan beri kesempatan siswa peroleh kebanggaan. Jadi dengan membacakan hasil tes siswa akan memperoleh kebanggaan sehingga mendorong siswa untuk berprestasi lebih baik. Pengamatan terhadap hasil tes formatif siklus II menunjukkan hasil yang baik dan memuaskan, dengan jumlah 22 siswa sudah mendapatkan nilai 70 keatas. Hasil yang baik umumnya diperoleh siswa yang berkemampuan tinggi dan sedang

\section{Pemabahasan}

Berdasarkan pelaksanaan perbaikan pembelajaran pada siklus I, diperoleh data terjadi peningkatan perhatian siswa sehingga suasana kelas lebih tenang. Namun masih ada beberapa siswa yang kurang memperhatikan pelajaran. Siswa sudah berani bertanya, dan melaksanakan tugas dengan baik. Metode yang digunakan tidak hanya ceramah dan tanya jawab, tetapi juga demonstrasi, penugasan serta latihan. Demonstrasi dalam bentuk alat peraga gambar anak di rumah dan di sekolah.

Dengan menjelaskan terlebih dahulu katakata yang tidak dipahami siswa, bahasa yang digunakan guru dalam menjelaskan materi hak anak dirumah dan di sekolah jadi mudah dipahami siswa. Siswa dalam mengerjakan tes formatif hasilnya ada peningkatan. Hal tersebut dapat diketahui dari hasil tes formatif perbaikan pembelajaran siklus I mengalami peningkatan dari sebelum perbaikan. Nilai rata-rata sebelum perbaikan 80,66 sedang setelah perbaikan siklus I menjadi 84,0. kemampuan peroranganpun juga mengalami peningkatan. Pada tes formatif sebelum perbaikan, siswa yang mendapat nilai lebih dari 65 ada 22 siswa $(83,33 \%)$, sedang pada siklus I menjadi 23 siswa $(86,67 \%)$.

Berikut ini kami sajikan data hasil tes formatif sebelum perbaikan dan setelah perbaikan pembelajaran siklus I dalam bentuk tabel.

\section{Tabel 1}

\section{Persentase Perolehan Nilai Sebelum Perbaikan}

\begin{tabular}{clc}
\hline No & \multicolumn{1}{c}{ Nama } & Nilai Pra Siklus \\
\hline 1 & ANDI GUNAWAN & 70 \\
\hline 2 & AGUS LIANA SARI & 40 \\
\hline 3 & ADIT PRABOWO & 60 \\
\hline 4 & BUDI HARTONO & 60 \\
\hline 5 & DILA ANDRESTA & 50 \\
\hline 6 & DARMAWAN & 40 \\
\hline 7 & EKO GUNAWAN & 40 \\
\hline 8 & FITRI ERAWAN & 50 \\
\hline 9 & HERWANDA & 70 \\
\hline 10 & IRANIKA & 80 \\
\hline 11 & MAWARDI & 60 \\
\hline 12 & MIRA GUSUITA & 60 \\
\hline 13 & MUHAMMAD & 70 \\
\hline & NANDA & 50 \\
\hline 14 & NANDA WAHYUDI & 50 \\
\hline 15 & PITA SARI & 40 \\
\hline 16 & PUTRI ANJANI & 30 \\
\hline 17 & RAJUANSYAH & 60 \\
\hline 18 & SRI WAHYUNI & 60 \\
\hline 19 & SATRIA & 50 \\
\hline 20 & SONI KUNCORO & 40 \\
\hline 21 & SURIANA & 30 \\
\hline 22 & SUNITA & 40 \\
\hline 23 & TONI SAPUTRA & 40 \\
\hline 24 & UNTUNG L TOBING & \\
\hline & & \\
\hline
\end{tabular}




\begin{tabular}{clc}
\hline 25 & $\begin{array}{l}\text { WAWAN } \\
\text { NURAHMAN }\end{array}$ & 50 \\
\hline 26 & WAHYUDI & 50 \\
\hline 27 & ZAINAL ABIDIN & 40 \\
\hline
\end{tabular}

Dapat diketahui bahwa jumlah siswa kelas I yang mendapat nilai 70 kebawah berjumlah 17 siswa dan yang mendapat nilai 70 keatas berjumlah 10 siswa, jadi rata-rata nilai kelas satu kelas baru mencapai 51,11. jadi peneliti perlu mengadakan perbaikan pembelajaran melalui siklus I. peneliti berusaha meningkatkan hasil tes anak dengan metode yang bervariasi dan menambah alat peraga yang lebih jelas.

Tabel 2

Persentase Perolehan Nilai Siklus I

\begin{tabular}{clc}
\hline NO & \multicolumn{1}{c}{ Nama } & $\begin{array}{c}\text { Nilai Pra } \\
\text { Siklus }\end{array}$ \\
\hline 1 & ANDI GUNAWAN & 80 \\
\hline 2 & AGUS LIANA SARI & 60 \\
\hline 3 & ADIT PRABOWO & 70 \\
\hline 4 & BUDI HARTONO & 70 \\
\hline 5 & DILA ANDRESTA & 50 \\
\hline 6 & DARMAWAN & 80 \\
\hline 7 & EKO GUNAWAN & 40 \\
\hline 8 & FITRI ERAWAN & 70 \\
\hline 9 & HERWANDA & 70 \\
\hline 10 & IRANIKA & 80 \\
\hline 11 & MAWARDI & 70 \\
\hline 12 & MIRA GUSUITA & 60 \\
\hline 13 & MUHAMMAD NANDA & 70 \\
\hline 14 & NANDA WAHYUDI & 70 \\
\hline 15 & PITA SARI & 70 \\
\hline 16 & PUTRI ANJANI & 50 \\
\hline 17 & RAJUANSYAH & 70 \\
\hline 18 & SRI WAHYUNI & 80 \\
\hline 19 & SATRIA & 70 \\
\hline 20 & SONI KUNCORO & 60 \\
\hline 21 & SURIANA & 70 \\
\hline 22 & SUNITA & 50 \\
\hline 23 & TONI SAPUTRA & 70 \\
\hline 24 & UNTUNG L TOBING & 60 \\
\hline 25 & WAWAN NURAHMAN & 70 \\
\hline 26 & WAHYUDI & 70 \\
\hline 27 & ZAINAL ABIDIN & 60 \\
\hline & & \\
\hline
\end{tabular}

Berdasarkan Tabel 2 dapat diketahui bahwa jumlah siswa kelas I, yang mendapatkan nilai 70 kebawah berjumlah 10 siswa dan yang mendapat nilai $70 \mathrm{ke}$ atas 17 siswa, jumlah semua siswa kelas I 27 siswa. Jadi nilai rata-rata satu kelas mencapai 66,30, jadi peneliti perlu mengadakan perbaikan pembelajaran melalui siklus II. Pada siklus I belum tuntas maka akan diadakan perbaikan agar pada siklus II peneliti merasa puas dengan hasil yang menemui ketuntasan.

1. Siklus II

Pada perbaikan pembelajaran siklus II ini, siswa lebih meningkatkan minat dan perhatiannya terhadap materi yang disampaikan. Siswa lebih menaruh perhatian karena untuk mendemonstrasikan alat peraga hak anak di rumah dan di sekolah menjadi lebih jelas. Adanya alat peraga berupa gambar hak anak di rumah dan di sekolah, siswa lebih memahami tentang pelajaran PKn. Penerapan metode tanya jawab dan ceramah bervariasi dalam pembelajaran tentang hak anak di rumah dan di sekolah sangat sesuai.

Pada saat siswa mengerjakan soal, guru memberikan bimbingan secara individu terutama terhadap siswa yang berkemampuan rendah sehingga sangat membantu pemahaman siswa terhadap materi yang diajarkan. Selain tes yang dilaksanakan pada saat pelaksanaan pembelajaran, guru juga memberikan tugas dirumah sehingga dapat meningkatkan ketrampilan siswa dalam menjawab pertanyaan. Guru dapat meningkatkan motivasi siswa dalam pembelajaran PKn. Hal ini dapat diketahui dari hasil tes formatif perbaikan pembelajaran siklus II yang mengalami peningkatan.

Tabel 4

Persentase Perolehan Nilai Siklus II

\begin{tabular}{clc}
\hline No & \multicolumn{1}{c}{ Nama } & Nilai Siklus II \\
\hline 1 & ANDI GUNAWAN & 80 \\
\hline 2 & AGUS LIANA SARI & 80 \\
\hline 3 & ADIT PRABOWO & 70 \\
\hline 4 & BUDI HARTONO & 70 \\
\hline 5 & DILA ANDRESTA & 70 \\
\hline 6 & DARMAWAN & 80 \\
\hline 7 & EKO GUNAWAN & 60 \\
\hline 8 & FITRI ERAWAN & 70 \\
\hline 9 & HERWANDA & 80 \\
\hline 10 & IRANIKA & 80 \\
\hline 11 & MAWARDI & 70 \\
\hline 12 & MIRA GUSUITA & 60 \\
\hline 13 & MUHAMMAD & 70 \\
\hline & NANDA & 80 \\
\hline 14 & NANDA WAHYUDI & 80 \\
\hline 15 & PITA SARI & 50 \\
\hline 16 & PUTRI ANJANI
\end{tabular}




\begin{tabular}{cll}
\hline 17 & RAJUANSYAH & 70 \\
\hline 18 & SRI WAHYUNI & 90 \\
\hline 19 & SATRIA & 80 \\
\hline 20 & SONI KUNCORO & 60 \\
\hline 21 & SURIANA & 70 \\
\hline 22 & SUNITA & 50 \\
\hline 23 & TONI SAPUTRA & 70 \\
\hline 24 & UNTUNG L TOBING & 70 \\
\hline 25 & WAWAN & 70 \\
& NURAHMAN & \\
\hline 26 & WAHYUDI & 70 \\
\hline 27 & ZAINAL ABIDIN & 80 \\
\hline
\end{tabular}

Tabel 4 menunjukkan bahwa nilai rata-rata pada tes formatif perbaikan pembelajaran siklus I 66,30 meningkat menjadi 71.48 pada siklus Kemampuan peroranganpun juga mengalami peningkatan. Pada siklus I siswa yang mendapat nilai lebih dari 70 ada $18(66,66 \%)$, sedangkan pada siklus II menjadi $22(81,48 \%)$. Hasil tersebut dapat dilihat pada hasil tes formatif perbaikan pembelajaran siklus II Berdasarkan tabel 4 dapat diketahui bahwa jumlah siswa kelas I SD 5 Rantau Panjang 27 siswa. Siswa yang mendapat nilai 70 ke bawah 5 orang, nilai 70 ke atas 22 orang. Jadi dalam Siklus II dalam perbaikan pembelajaran peneliti menyatakan sudah tuntas, karena nilai rata-rata mencapai 71,48 (81,48 \%). Maka dari itu peneliti tetap memotivasi terhadap siswa agar nilainya selalu memenuhi ketuntasan.

\section{KESIMPULAN DAN SARAN Simpulan}

Dari hasil perbaikan pembelajaran terhadap materi hak anak di rumah dan di sekolah di kelas I SD Negeri 5 Rantau Panjang Kecamatan Simpang Hilir Kabupaten Kayong Utara menghasilkan kesimpulan sebagai berikut : (1) Minat dan perhatian siswa kelas I terhadap mata pelajaran PKn dapat ditingkatkan melalui pengkondisian awal siswa secara intensif dan melibatkan siswa dalam penggunaan alat peraga. (2) Penggunaan alat peraga gambar hak anak di rumah dan di sekolah dapat meningkatkan pemahaman siswa. (3) Kata hak adalah suatu kata yang abstrak, penjelas, sulit dipahami siswa yang berfikirnya kategori operasional konkrit. (4) Penggunaan metode tanya jawab dan ceramah bervariasi dapat lebih meningkatkan pemahaman siswa dan ketrampilan siswa. (5)Penjelasan guru sulit dipahami bila ada kata-kata yang tidak dikenal oleh siswa.

\section{Saran}

Berdasarkan kesimpulan diatas, saransaran sebagai tindak lanjut adalah : (1) Bagi Guru : (a). Selalu memperhatikan kondisi awal siswa dalam pembelajaran, (b) Menggunakan alat peraga dalam menjelaskan materi, agar bisa lebih dipahami siswa yang taraf berfikinnya kategori operasional konkrit. (c) Memilih dan menggunakan metode yang bervariasi dalam menyajikan materi pembelajaran agar siswa tidak bosan. (d) Memotivasi siswa agar lebih berminat dalam pembelajaran. (e) Memberikan pelayanan kepada siswa dengan penuh dedikasi dengan memperhatikan perbedaan individu siswa. Bagi Sekolah ;

Menciptakan iklim belajar yang kondusif, agar siswa dapat lebih berkonsentrasi dalam pembelajaran

\section{DAFTAR RUJUKAN}

Ali Abin Syamsudin, MA. Prof Dr, dkk, 2005, Profesi Keguruan 2, Jakarta : Pusat Penerbitan Universitas Terbuka.

A Sunawi Zainuh, M.Ed. Prof Dr, 2005, Tes dan Asesmen di $S D$, Jakarta : Pusat Penerbitan Universitas Terbuka.

Mulyani Sumantri, dkk, 2005, Perkembangan Peserta Didik, Jakarta : Pusat Penerbitan Universitas Terbuka.

Rini Ningsih, MPd, 2005, Belajar dan Pembelajaran 2, Jakarta : Pusat Penerbitan Universitas Terbuka.

Suparna Nana, dkk, 2006, Pendidikan Kewarganegaraan untuk SD Kelas I, Jakarta : Penerbit Erlangga.

Wardani I.G.A.K, dkk, 2003, Penelitian Tindakan Kelas, Jakarta : Pusat Penerbitan Universitas Terbuka.

Widiastuti Setiati, dkk, 2008, Pendidikan

Kewarganegaraan SD/MI, Kelas I, Jakarta :

Pusat Perbukuan Departemen Pendidikan

Nasional. 